\title{
REVERSALS IN LAND GRANT RULINGS
}

\section{By JACOB E. REITzENSTEIN}

"Withhold from sale all lands situated in the odd-numbered sections within five miles on each side of the Des Moines river, above Raccoon Forks." Thus read an order filed in Iowa City, under date of June 1, 1849. It was placed on record in the office of the registrar and receiver of the Iowa City land office. The directive came from the commissioner of the general land office.

Robert J. Walker, secretary of the treasury under Pres. James K. Polk, had received a firm protest from all of Iowa's national senators and representatives protesting against interpretations of the United States government grant that involved countless acres in the new state.

Commissioner Richard M. Young, of the general land office, had issued his interpretation in February 1848, and he had construed the so-called "Des Moines River Grant" to that Iowa was entitled to the "alternate sec tions within five miles of the Des Moines river, throughout the whole extent of the river, within the limits" of the Hawkeye commonwealth. Thus construed, the grant naturally included as state property the alternate sections above the Raccoon Forks.

About mid-June, that same year, however, a proclamation was issued, whereunder some of those very lands were thrown on the market for public sales. The Iowa board of public works protested to the general land office commissioner, and to the state land office, which was to conduct the proposed sale.

Iowa law-makers in the U. S. congress, who rebelled against the interpretation that permitted such sales, were Hon. William Thompson of Mt. Pleasant and Hon. Shepherd Leffler, of Burlington, both democratic leaders.

Both, too, had served in the Thirtieth and Thirty-first sessions at Washington, from 1847 to 1851 , and Mr. Leff- 
ler was in the Twenty-ninth (first for Iowa) session, from 1845 to 1847 , during which Iowa had been honored with a successor to a mere "delegate." Actual statehood, of course, came in 1846.

During the 1848-1855 and 1848-1859 periods, respectively, Hon. Augustus C. Dodge and Hon. George W. Jones were the U. S. senators. Secretary Walker, however, held in 1849 , that the grant extended the whole length of the Des Moines river, in Iowa.

Hon. Thomas Ewing, secretary of the interior, under Pres. Zachary Taylor, reversed Secretary Walker's opinion, however, in April, 1849. Mr. Ewing also ordered the lands in dispute to be withheld from the sales until congress clarified the verbal muddle, and the variouslyinterpreted grant became primer-like reading (although he didn't use that specific language, of course.)

Came then another appeal, the Iowa authorities sending it to President Taylor. The doughty general forthwith shifted the problem to Atty. Gen. Reverdy Johnson, who duly decreed: "The grant goes to the very mouth of the Des Moines."

Before the opinion reached print, however, President Taylor died. (July 9, 1850). Came Vice Pres. Millard Fillmore to the chair, and with him another reversal, in that his attorney general (the returned J. J. Crittenden) ruled that the Raccoon Forks boundary was the limit.

Secretary of the Interior A. H. H. Stuart agreed with Mr. Crittenden at first, but (exercising the right of women secretaries, and even presidents, to change one's mind), he ultimately reversed Mr. Crittenden and himself.

He permitted the case, however, to go to President Fillmore and the cabinet. Those august arbiters ended the protracted battle, by decreeing that the state of Iowa was right. Thus 271,572.24 acres above Raccoon Forks went on the market.-Iowa City Press-Citizen. 
Copyright of Annals of Iowa is the property of State of Iowa, by \& through the State Historical Society of Iowa and its content may not be copied or emailed to multiple sites or posted to a listserv without the copyright holder's express written permission. However, users may print, download, or email articles for individual use. 